\title{
Konsep Model Bisnis Inkubasi Online dengan Perspektif Triple Helix
}

\author{
Khoirunnissa Nur Abidah, Imam Baihaqi, dan Satria Fadil Persada \\ Departemen Manajemen Bisnis, Institut Teknologi Sepuluh Nopember (ITS) \\ e-mail: ibaihaqi@mb.its.ac.id
}

\begin{abstract}
Abstrak-UKM adalah salah satu sektor penyumbang PDB Nasional tersebar di Indonesia yakni sebesar 60,6\%. Dalam rangka mendukung pertumbuhan dan perkembangan UKM, perlu adanya sinergi dari berbagai pihak mulai dari akademisi, industri, dan perguruan tinggi sebagai pemangku kepentingan dalam triple helix pada sebuah inkubator bisnis. Inkubator bisnis merupakan alat yang banyak digunakan oleh banyak negara berkembang termasuk Indonesia, sebagai sarana pengembangan usaha baru dan atau usaha kecil dan menengah (UKM). Definisi inkubator bisnis sendiri adalah lembaga yang menaungi sebuah inkubasi bisnis dalam proses pembinaan bagi usaha kecil dan atau pengembangan produk baru serta penyediaan sarana dan prasarana usaha, pengembangan usaha, dan dukungan manajemen serta teknologi. Implementasi inkubator bisnis dengan model triple helix dapat diwujdukan melalui penerapan teknologi digital di dalamnya. Sebagai bentuk upaya bertahan dan meningkatkan daya saing di era revolusi industri 4.0, banyak model bisnis yang bertransformasi ke dunia digital. Sehingga pada penelitian ini penulis bermaksud untuk memberikan rekomendasi model bisnis serta prototipe sistem untuk membangun sebuah platform digital yang dapat dikembangkan oleh inkubator bisnis berdasarkan konsep triple helix. Implementasi penelitian ini menggunakan studi kasus inkubator bisnis Institut Teknologi Sepuluh Nopember (ITS) Surabaya. Penelitian ini menggunakan kerangka kerja BMC, desain UML, dan BPMN untuk membangun platform. Platform tersebut adalah sistem E-Incubator dimana pelayanan UKM dikemas dalam sebuah konsep secara elektronik melalui aplikasi berbasis web. Melalui platform tersebut, UKM dapat menerima pelayanan inkubator dengan lebih tersistem sehingga memiliki database yang sangat berguna dalam setiap aspek pengembangan. Rekaman database dapat disimpan dalam sistem untuk memberikan dukungan dan bantuan yang efisien sesuai dengan kebutuhan UKM. Selain UKM, investor juga dapat menggunakan sistem ini sebagai sarana investasi yang mudah dan terjamin. Bagi industri pemerintah maupun swasta, sistem ini dapat menjadi fasilitas untuk memenuhi kebutuhan industri melalui lelang UKM.
\end{abstract}

Kata Kunci-Business Model Camvas, Digital Platform, Inkubator Bisnis, Prototipe, UKM

\section{PENDAHULUAN}

G EJOLAK erekonomian global yang terjadi akhir-akhir ini mulai dari langkah normalisasi kebijakan moneter di Amerika Serikat, kebijakan perang dagang, dan kebijakankebijakan lainnya yang telah dirasakan seluruh dunia terutama negara berkembang dalam bentuk peningkatan suku bunga dolar, menurunnya arus modal, dan adanya ketidakpastian perdagangan internasional [1]. Berbagai upaya telah dilakukan pemerintah untuk menjaga stabilitas dan keberlanjutan perekonomian di Indonesia melalui beberapa aspek yang harus dikelola antara lain sektor rill yang ditunjukkan dengan indikator pertumbuhan ekonomi atau Produk Domestik Bruto (PDB). Faktanya, presentase penyumbang PDB terbesar Indonesia saat ini adalah UKM yakni sebesar $60,6 \%$. Untuk dapat memaksimalkan peran UKM, dikenal adanya inisiasi sebuah inkubator bisnis yang menjadi alat penting pembangunan perekonomian dalam suatu negara terutama negara berkembang.

Inkubator bisnis merupakan alat yang banyak digunakan oleh banyak negara berkembang termasuk Indonesia, sebagai sarana pengembangan usaha baru dan atau usaha kecil dan menengah (UKM). Definisi inkubator bisnis sendiri adalah lembaga yang menaungi sebuah inkubasi bisnis dalam proses pembinaan bagi usaha kecil dan atau pengembangan produk baru serta penyediaan sarana dan prasarana usaha, pengembangan usaha, dan dukungan manajemen serta teknologi. Inkubator bisnis merupakan tuntutan dari the new of technology global, yang terjadi karena adanya perubahan yang cepat dan signifikan dibidang teknologi, telekomunikasi, dan digitalisasi;adanya deregulasi dan globalisasi. Perubahan tersebut memaksa adanya perubahan pada setiap pelakunya mulai dari skala negara, perusahaan/ organisasi, dan individu.

Mengingat peranan inkubator bisnis dalam menciptakan wirausaha baru yang tangguh dan mampu menjadi salah satu upaya dalam pengembangan UKM, perlu adanya inovasi terbaru bagi Inkubator dalam era global saat ini. Dalam suatu inkubasi bisnis, diperlukan sinergi dan penguatan kelembagaan dalam mengoptimalkan peran inkubator bisnis untuk menciptakan wirausaha baru dan membantu pengembangan UKM di Indonesia. Saat ini keberadaan inkubator bisnis secara legal telah didukung oleh Peraturan Presiden No. 27 Tahun 2013 tentang Pengembangan Inkubator Wirausaha. Implementasi dari Pipres tersebut dapat didukung melalui sinergi pemerintah, pihak swasta, dan perguruan tinggi dalam mengoptimalkan peran inkubator.

Selama ini, pemerintah, pihak swasta, dan perguruan tinggi yang merupakan lembaga-lembaga pendiri dan pemain utama dalam inkubator bisnis menjalankan peran masing-masing dalam program inkubasinya dengan tujuan dan fokus yang berbeda. Kolaborasi dan kerjasama antara ketiga pihak tersebut dalam model triple helix dapat memberikan inovasi 


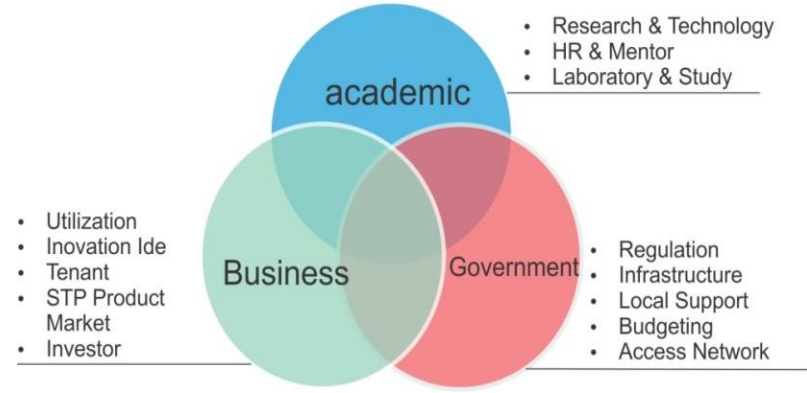

Gambar 1. Triple Helix

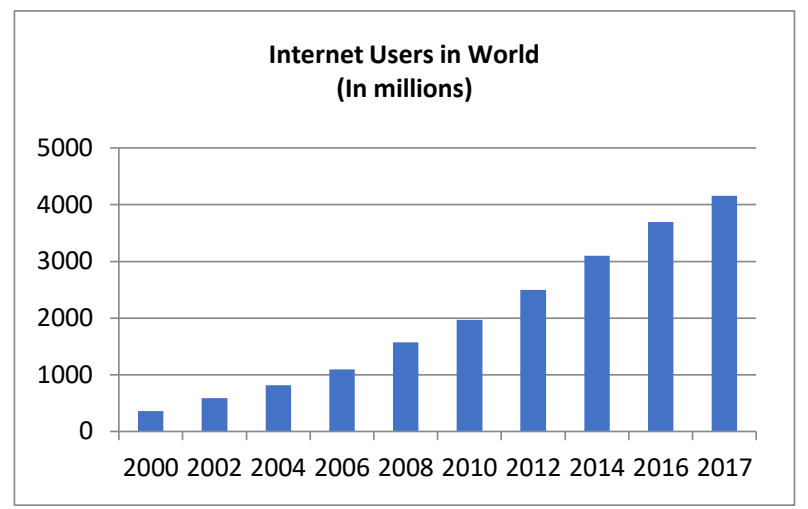

Gambar 2. Peningkatan Pengguna Internet di Dunia (Sumber: Internet Wold Stats, 2018)

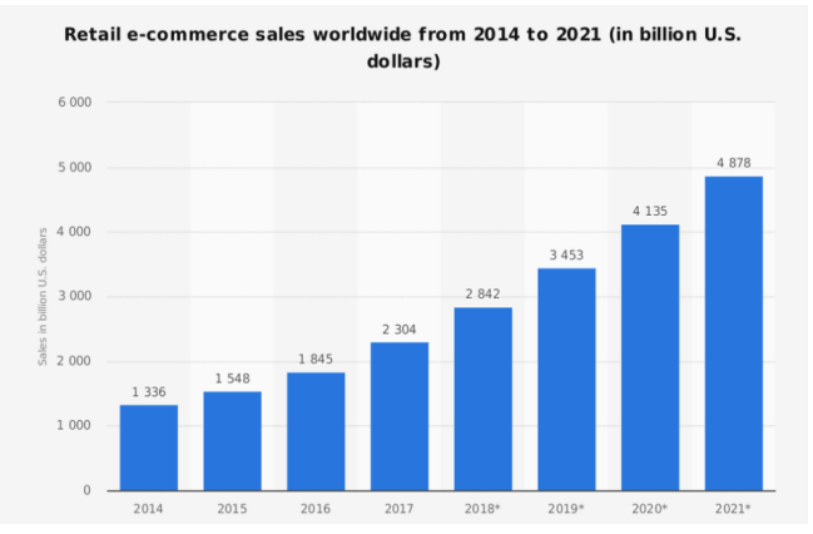

Gambar 3. Pertumbuhan Penjualan e-commerce (Sumber: Statista, 2018)

terbaru dalam sebuah inkubator bisnis. Konsep triple helix seperti yang diilustrasikan pada Gambar 1, adalah sinergi dan penyatuan tiga kalangan yang terdiri dari kalangan akademik, bisnis atau industri, dan pemerintah [2]. Tujuan utama dalam penggunaan konsep ini adalah untuk membentuk efektifitas serta efisiensi dalam mendukung penciptaan usaha baru dan atau perkembangan usaha kecil dan menengah.

Inkubator bisnis menggunakan konsep triple helix sebagai strategi pengembangan yang terpadu dan berkelanjutan, diharapkan dapat menjadi sarana yang efisien dan efektif dalam mendukung pengembangan usaha kecil dan menengah di Indonesia. Inkubator bisnis dapat diwujudkan dalam model triple helix III, dinama pihak akademisi sebagai pelaku aktif dalam hubungan kerjasama dengan pemerintah dan industri

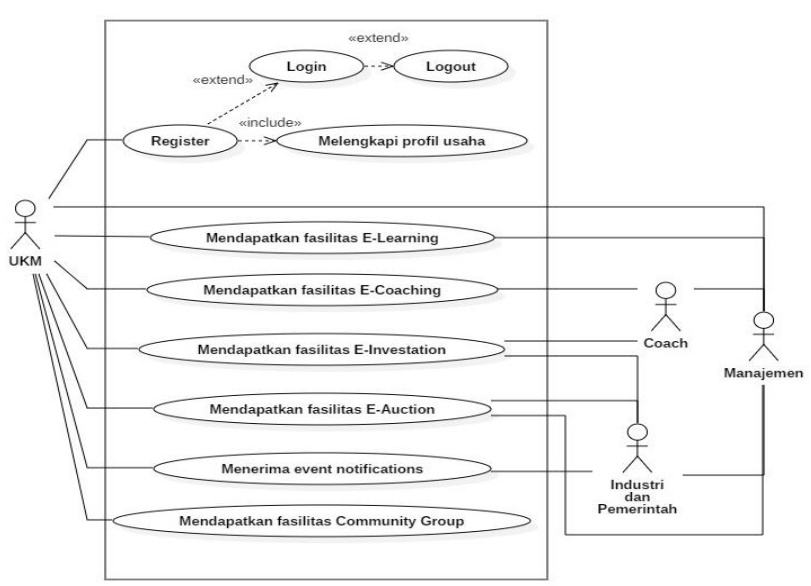

Gambar 4. Use Case Diagram

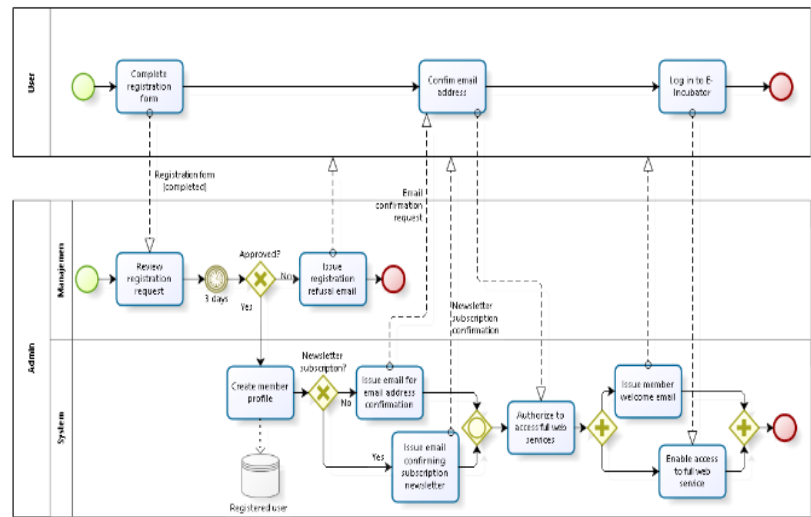

Gambar 5. Pengelolaan Sistem

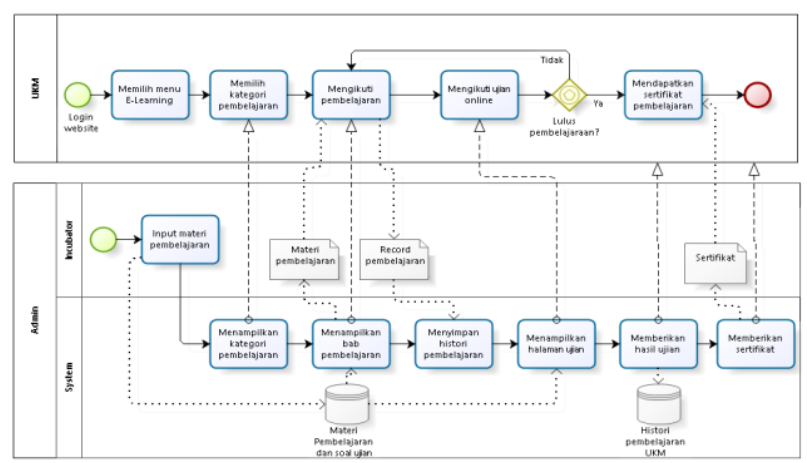

Gambar 6. Pengelolaan E-Learning

dalam model yang seimbang, agar dapat lebih dinamis dan dapat menciptakan keseimbangan antara sistem yang berbeda.

Model bisnis inkubator dengan konsep triple helix dapat di realisasikan dengan lebih efektif melalui penerapan teknologi. Banyak model bisnis di era saat ini yang melakukan transformasi ke dunia digital. Hal ini sebagai bentuk penyesuaian diri di era revolusi industri 4.0 demi meningkatkan daya saing perusahaan. Revolusi industri terkini atau generasi keempat telah mendorong sistem otomatisasi di dalam semua proses aktivitas. Teknologi internet yang semakin masif tidak hanya menghubungkan jutaan manusia diseluruh dunia tetapi juga telah menjadi basis bagi transaksi perdagangan dan berbagai lini bisnis barang maupun jasa secara online [3]. Sehingga banyak bermunculan $e$-business di 


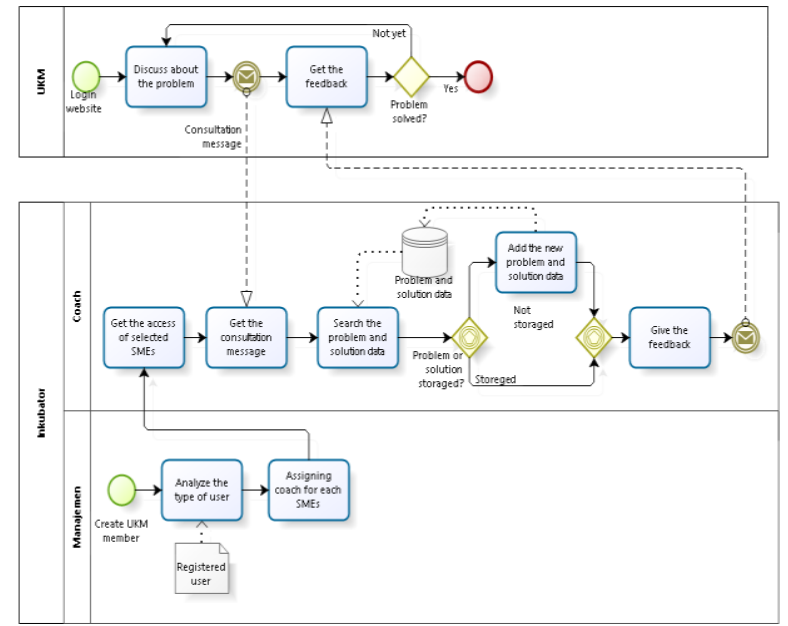

Gambar 7. Pengelolaan E-Coaching
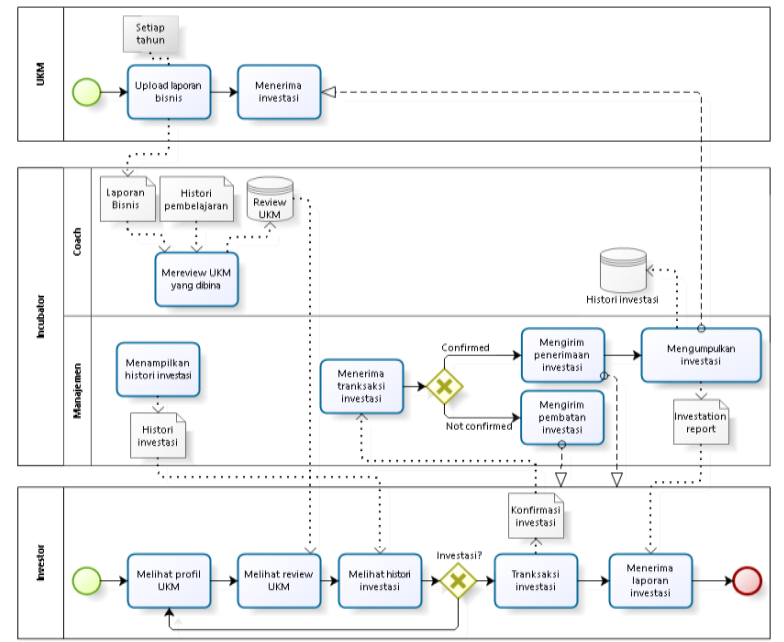

Gambar 8. Pengelolaan E-Investation
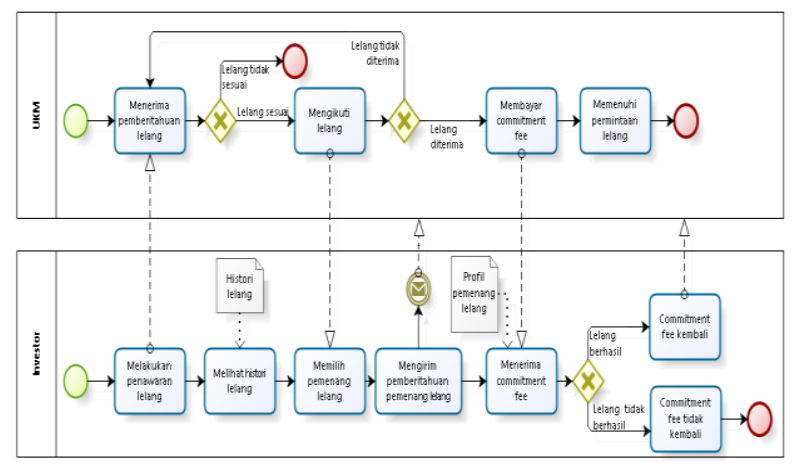

Gambar 9. Pengelolaan E-Auction

dunia didukung dengan penggunaan internet yang meningkat drastis dalam beberapa tahun terakhir seperti yang ditunjukkan pada Gambar 2.

Bisnis digital atau E-Business (electronic business) yang berasal dari istilah seperti "e-mail" dan "e-commerce", tidak hanya membeli dan menjual tetapi juga melayani pelanggan dan berkolaborasi dengan mitra bisnis. Peningkatan bisnis digital di dunia dapat dilihat melalui peningkatan penjualan ecommerce seperti pada Gambar 3. Begitu juga dengan inkubator bisnis telah mengalami perkembangan menjadi
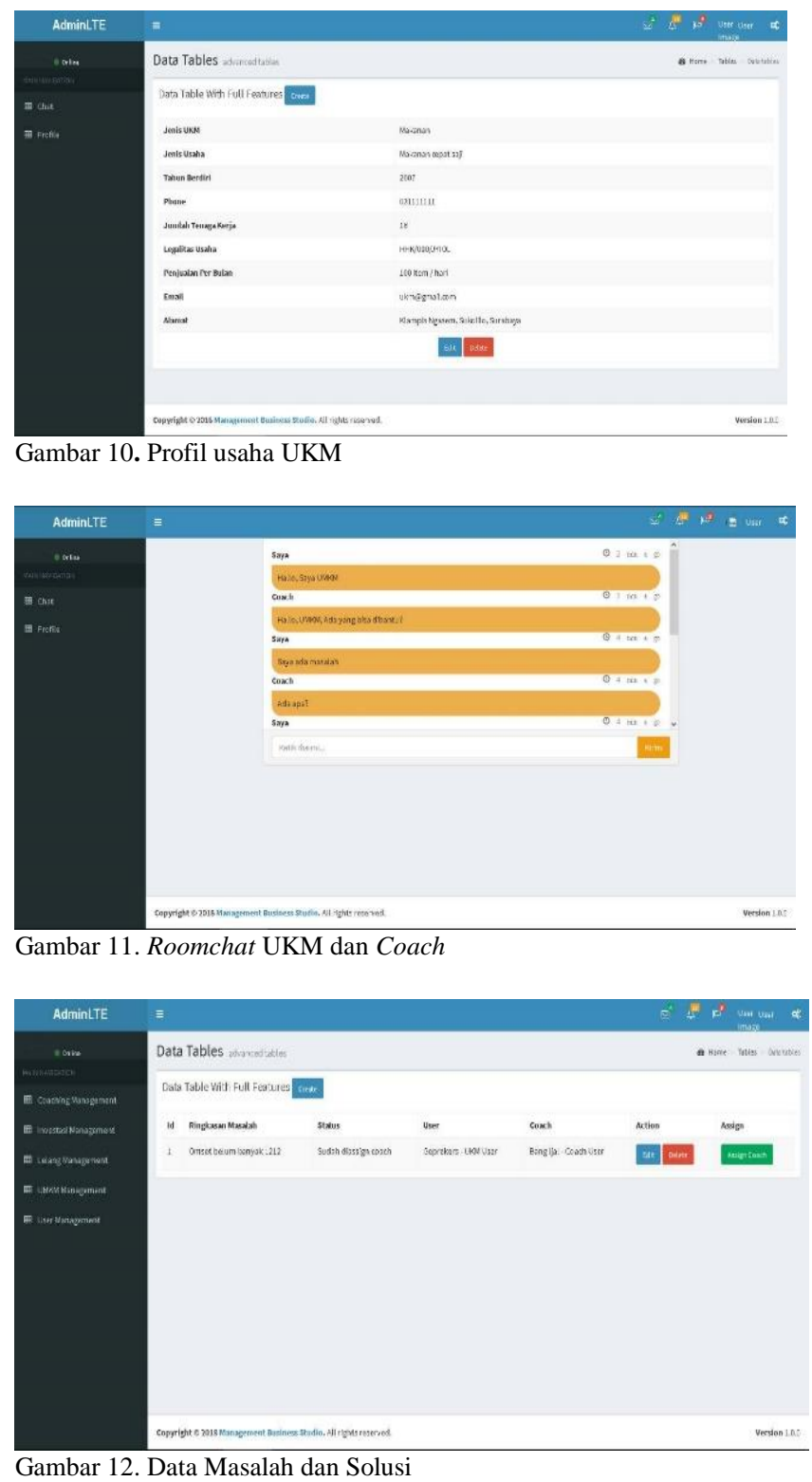

bisnis yang menyediakan layanan secara online sehingga munculnya inkubator virtual di beberapa negara.

Munculnya inkubator virtual dimulai dari adanya dot-com bubble burst. Hal ini telah membuat operasi bisnis inkubator berubah. Banyak bisnis inkubator yang mengubah model bisnisnya secara virtual setelah era dot-com bubble. Inkubator virtual muncul untuk menyediakan layanan diluar batas bangunan fisik dan memperluas jangkauan geografis yang dapat dilayani oleh sebuah inkubator [4]. Mengingat bahwa UKM memiliki berbagai kebutuhan, inkubasi virtual menyediakan berbagai layanan dan tools yang lebih beragam dan melalui cara yang lebih efektif terutama dalam hal biaya.

Sehingga pada penelitian ini penulis bermaksud untuk memberikan rekomendasi model bisnis serta prototipe sistem untuk membangun sebuah platform digital yang dapat dikembangkan oleh inkubator bisnis berdasarkan konsep triple helix. Platform tersebut adalah sistem E-Incubator dimana 


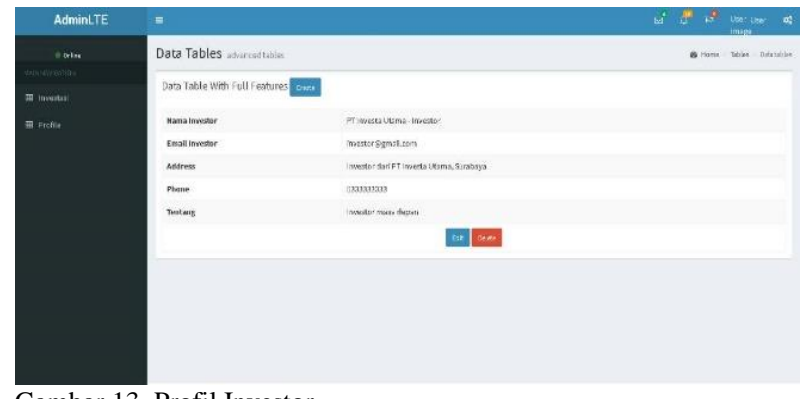

Gambar 13. Profil Investor

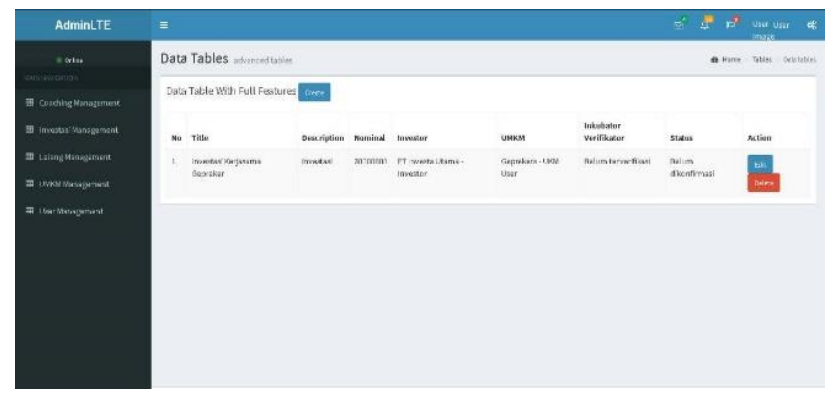

Gambar 14. Histori Tranksaksi Investasi

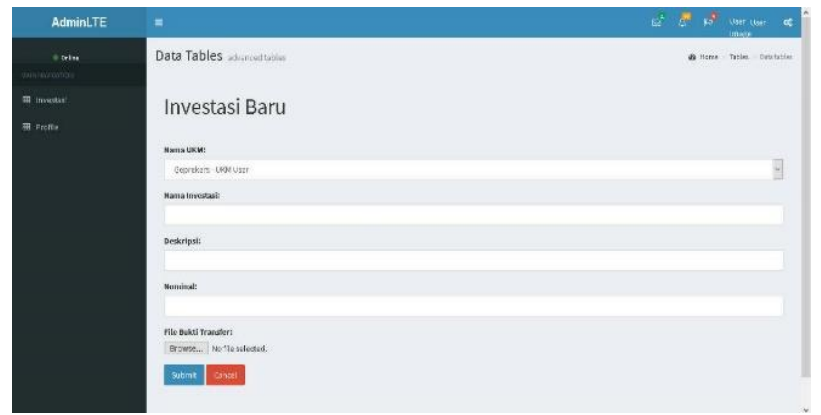

Gambar 15. Form Investasi Baru

pelayanan UKM dikemas dalam sebuah konsep secara elektronik melalui aplikasi berbasis web. Melalui platform tersebut, UKM dapat menerima pelayanan inkubator dengan lebih tersistem sehingga memiliki database yang sangat berguna dalam setiap aspek pengembangan. Rekaman database dapat disimpan dalam sistem untuk memberikan dukungan dan bantuan yang efisien sesuai dengan kebutuhan UKM. Selain UKM, investor juga dapat menggunakan sistem ini sebagai sarana investasi yang mudah dan terjamin. Bagi industri pemerintah maupun swasta, sistem ini dapat menjadi fasilitas untuk memenuhi kebutuhan industri melalui lelang UKM.

Implementasi penelitian ini menggunakan studi kasus pada inkubator bisnis yang ada di perguruan tinggi Institut Teknologi Sepuluh Nopember (ITS) Surabaya. Inkubator tersebut adalah UPT Inkubator Indusrti ITS yang merupakan salah satu unit usaha dibawah Badan Pengembangan dan Pengelola Usaha (BPPU) ITS dalam rangka menunjang tujuan Tri Dharma Perguruan Tinggi ITS.

E-Incubator adalah platform dimana para peserta inkubasi (tenant) dapat melakukan coaching dengan para mentor, mendapatkan pengetahuan manajemen melaui e-learning, memperoleh investasi, dan akses pasar dengan mudah secara online melalui portal website. Definisi platform sendiri adalah
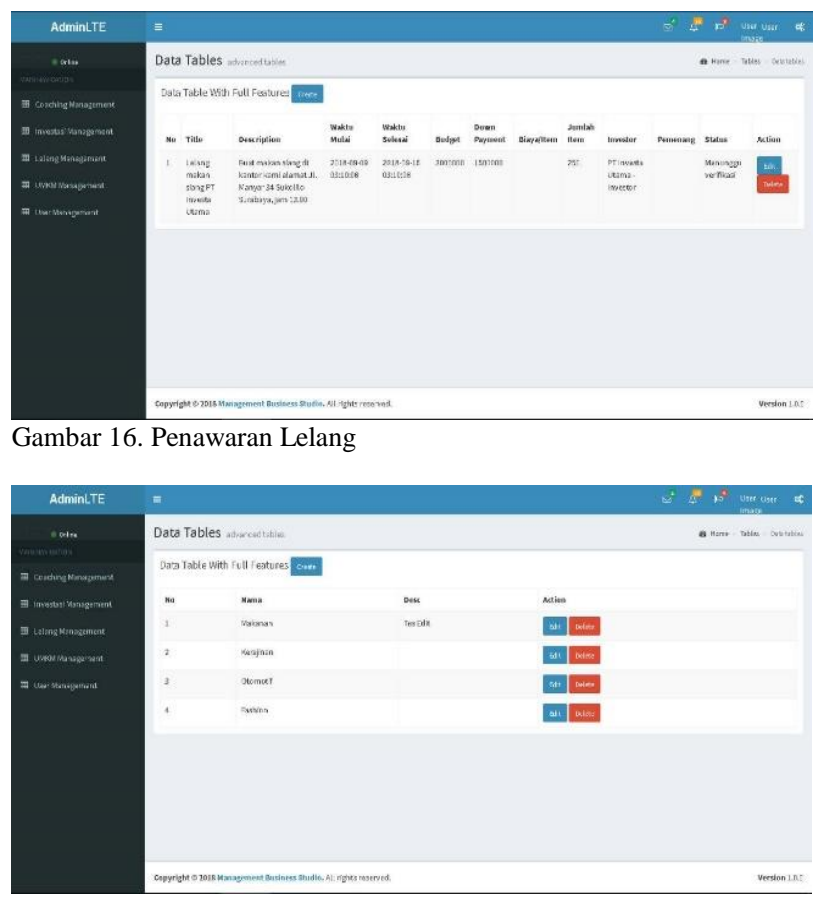

Gambar 17. Daftar Produk

produk atau layanan yang menyatukan kelompok pengguna dalam jaringan dua sisi (two-sided networks) [5].

Dorongan teknologi global membuat segala hal bertransformasi ke dunia digital. E-Incubator merupakan inovasi teknologi dalam bisnis inkubator yang dapat memberikan akses mudah kepada para tenant untuk mendapatkan program-program dalam inkubasi bisnis yang ditawarkan melalui jaringan yang menghubungkan antara triple helix dengan UKM.

Penerapan teknologi informasi dan komunikasi dalam inkubator memiliki banyak manfaat keunggulan. Beberapa diantaranya adalah akses yang mudah dan kapanpun, UKM dapat melakukan coaching secara virtual dengan mentornya setiap saat melalui platform digital. Permasalahanpermasalahan yang dihadapi oleh UKM dapat dikonsultasikan kapanpun tanpa harus bertatap muka. Hasil konsultasi berupa masalah dan solusi pun dapat menjadi database bagi para coach atau mentor sehingga dapat melakukan repeating issue terhadap UKM lain yang memiliki kasus yang sama. Database tersebut juga dapat menjadi bahan pertimbangan dalam melaksanakan program yang diberikan. UKM dapat memperoleh pembelajaran melalui e-learning yang dapat di pelajari kapanpun dan dapat dilakukan berulang-ulang sehingga tercapai pembelajaran yang efisien. Pemerintah dan perusahaan besar dapat bertranksaksi investasi dengan lebih mudah. Industri-industri dapat memenuhi kebutuhannya menggunakan produk atau jasa UKM melalui lelang secara online.

Inkubator dapat mengoptimalkan fungsi kewirausahaan sebagai gerakan ekonomi rakyat. Dengan peran serta berbagai pihak diyakininya akan meningkatkan rasio wirausaha Indonesia yang saat ini persentasenya masih sangat rendah. 
Melalui model triple helix III dalam konsep inkubator bisnis yang dilakukan secara online diharapkan dapat memberikan fasilitas bagi UKM untuk tumbuh dan berkembang dengan daya saing global. Melalui perancangan bisnis model yang tepat dan perancangan konstruksi platform dalam E-Incubator diharapkan dapat menjadi inovasi inkubator bisnis dalam era teknologi global saat ini.

\section{METODE PENELITIAN}

Dalam penelitian ini penulis melakukan analisis model bisnis E-Incubator menggunakan kerangka kerja business model canvas (BMC). Analisis dilakukan dengan menyusun BMC pada UPT Inkubator Industri ITS saat ini berdasarkan hasil wawancara dan observasi kemudian melakukan analisis perbaikan BMC berdasarkan penerapan sistem. Setelah model bisnis dianalisis, penulis melakukan perancangan sistem dengan membuat dokumen desain perancangan sistem yang sebagai pedoman oleh pengembang dalam membangun prototipe sistem E-Incubator.

\section{HASIL DAN DISKUSI}

\section{A. Analisis Model Bisnis Saat Ini}

Analisis model bisnis saat ini dilakukan berdasarkan wawancara oleh kepala inkubator dan observasi di UPT Inkubator Industri ITS. Hasil yang didapatkan adalah saat ini value proposition yang ditawarkan oleh inkubator adalah Mendorong lahirnya wirausaha tangguh yang memiliki karakter produk inovatif yang didukung riset dalam proses pengembagan produk dan mendukung lahirnya produk inovasi yang memiliki nilai tambah tinggi dan berdaya saing kuat. Pelayanan yang diberikan oleh UPT Inkubator Industri ITS diperuntukkan bagi startup company yang ada di Surabaya mulai dari mahasiswa ITS, alumni ITS, maupun alumni dari institut lainnya hingga masyarakat umum yang ingin memulai bisnisnya atau pengembangan usaha bisnisnya. Nilai proporsisi yang diberikan kepada tenant disalurkan melalui programprogram inkubator bisnis Dalam menjaga hubungan dengan tenant, UPT Inkubator Industri ITS memberikan programprogram pelayanan seperti seminar dan pameran yang diadakan 1-2 kali dalam setahun.

Dalam menjalankan program dan pelayanan inkubator, pendapatan yang diterima berasal dari dana anggaran perguruan tinggi untuk pengembangan industri wirausaha serta bantuan dana dari partnership dan Pmerintah Kota Surabaya. Untuk melaksanakan program dan pelayanan inkubator, dibutuhkan sumber daya manusia sebagai tim manajemen untuk menjalankan aktivitas bisnis inkubator. Aktivitas-aktivitas bisnis yang dilakukan oleh inkubator its mulai dari pengelolaan operasional sehari-hari, melakukan kerjasama, mengurus administrasi pendanaan, melakukan perencangaan dan pengembangan kedepan, serta mengadakan program dan pameran inkubator. Dalam mendukung aktivitas bisnis UPT Inkubator Industri ITS, dibutuhkan kerjasama dengan berbagai pihak dalam hal ini kerjasama yang dilakukan adalah bekerjasama dengan Kementrian Riset, Teknologi, dan Pendidikan Tinggi Republik Indonesia, PT PJB, dan Pemerintah Kota Surabaya. Biaya-biaya yang diperlukan dalam menjalankan aktivitas bisnis inkubator adalah biaya operasional pelaksanakan program dan layanan yang diberikan.

\section{B. Perbaikan Model Bisnis}

Customer segments E-Incubator adalah pengguna dari sistem aplikasi web tersebut atau disebut dengan istilah user. E-Incubator merupakan sistem berdasarkan konsep triple helix sehingga segmen pelanggannya adalah UKM; investor yang terdiri dari lembaga pemerintah, BUMN/BUMD, perusahaan swasta; dan Industri yang membutuhkan supplier. Sedangkan value proposition yang diberikan oleh E-Incubator adalah Menyediakan digital platform UKM untuk tumbuh dan berkembang dalam lembaga inkubator berdasarkan konsep triple helix melalui fiturnya (e-learning, e-coaching, $e$ investation, e-auction); menyediakan digital platform bagi investor untuk mencari partner; dan menyediakan digital platform bagi perusahaan industri untuk mencari supplier.

Untuk menjaga hubungan dengan pelanggan, Customer Relationship yang diberikan adalah memudahkan proses coaching, investasi, dan lelang; adanya komunitas UKM; adanya Events; serta Membership. alam menyampaikan proposisi nilai kepada segmen, channel yang digunakan untuk E-Incubator adalah aplikasi berbasis web. Dalam jangka panjang, aplikasi ini juga bisa dikembangkan kedalam Apps. Key Resources dalam sistem inkubator ini terdiri dari tim manajemen, Coach, dan tim pengembang (Developer). Key Activities yang perlu dilakukan adalah mulai dari pengelolaan operasional inkubator, melakukan kerjasama dan sponsor, dan pengembangan dan perawatan website. Key Partnership yang dituju dalam sistem ini adalah Kementrian Koperasi-UKM, Kementrian perekonomian, BUMN/BUMD/Instansi terkait, dan Perusahaan Swasta.Revenue Streams yang diperoleh dari sistem dapat berasal dari pendapatan operasional dan pendapatan dana dukungan/tunjangan (PKBL-BUMN, Dana MAP, sponsorship, dan partnership). Sedangkan Cost Structure terdiri dari biaya operasional, biaya pemasaran dan campaign, biaya pengembangan dan perawatan sistem.

\section{Use Case Diagram}

Use case diagram berisi mengenai interaksi antara sekelompok proses dengan sekelompok aktor, menggambarkan fungsionalitas dari sebuah sistem yang dibangun dan bagaimana sistem berinteraksi dengan dunia luar. Use case diagram dapat digunakan selama proses analisis untuk menangkap kebutuhan sistem dan untuk memahami bagaimana sistem seharusnya bekerja. Use case diagram dalam sistem ini dapat dilihat pada Gambar 4.

\section{D.BPMN Design}

BPMN Design terdiri atas sebagai berikut:(1)BPMN Pengelolaan Sistem dapat kita lihat pada Gambar 5; (2)BPMN Pengelolaan E-Learning dapat dilihat pada Gambar 6; 
(3)BPMN Pengelolaan E-Coaching dapat dilihat pada Gambar 7:(4) BPMN Pengelolaan E-Investation dapat dilihat pada Gambar 8; 5) BPMN Pengelolaan E-Auction dapat dilihat pada Gambar 9.

\section{E. User Interface}

Tujuan dibangunnya user interface adalah agar sistem mudah dimengerti dan dipelajari, dapat mendukung pekerjaan pengguna secara efisien, aman, dan familiar. Berikut adalah desain antar muka system. mbar 10 menunjukkan halaman bagi UKM melengkapi profil usaha yang dapat dilihat oleh investor atau penawar lelang. Setelah menjadi tenant inkubator dan mendapat akses login website, UKM harus melengkapi profil usaha terlebih dahulu sebelum menggunakan fitur-fitur lainnya.

Gambar 11 merupakan halaman roomchat antara coach dengan UKM. UKM dapat berkonsultasi mengenai permasalahan yang sedang dihadapai ataupun berdiskusi terkait wawasan manajemen usaha. Setiap data permasalahan yang telah dikonsultasikan beserta solusi yang telah diberikan oleh coach dapat disimpan menjadi database masalah dan solusi. Database ini dapat digunakan oleh coach lain sehingga dapat memberikan masukan yang serupa ketika UKM lain mengalami permasalahan yang sama. ambar 12 merupakan halaman tampilan database masalah dan solusi yang dapat diakses oleh coach. Coach dapat menambahkan data maupun melakukan pencarian terkait topik masalah dan solusi.

UKM juga dapat memperoleh akses investasi melalui fitur yang ada di aplikasi website. Industri besar dan pemerintah sebagai investor juga perlu melengkapi profil sebagai pengguna aplikasi website terlebih dahulu. Gambar 13 menunjukkan halaman profil investor. Selain dapat melihat profil UKM, industri besar dan pemerintah juga dapat melihat histori tranksaksi investasi yang diperoleh UKM sebelumnya seperti yang ditunjukkan pada Gambar 14. Industri besar dan pemerintah dapat mulai memberikan investasi kepada UKM yang dianggapnya menarik dengan memilih menu Investasi Baru. Menu form Investasi Baru dapat dilihat pada Gambar 15.. Industri besar dan pemerintah yang sedang melaksanakan acara disuatu tempat sehingga membutuhkan misalkan catering, ataupun sedang membutuhkan barang atau jasa, dapat melakukan penawaran lelang terhadap UKM untuk memenuhi kebutuhannya. Gambar 16 merupakan penawaran lelang yang di post oleh industri besar dan pemerintah. UKM yang terpilih mengikuti lelang dapat diketahui history lelang dan profil usahanya. Gambar 17 merupakan tampilan histori lelang yang telah diikuti oleh UKM.

\section{SIMPULAN DAN SARAN}

Berdasarkan analisis yang telah dilakukan, hasil rekomendasi bisnis model telah dibuat sebagai dasar perancangan sistem Incubator Electronic (E-Incubator) berdasarkan konsep triple helix. Rekomendasi bisnis model dapat menjadi acuan dasar dalam melakukan strategi penerapan E-Incubator sebagai sistem pengembangan UKM yang dapat dikembangkan oleh lembaga inkubator bisnis.

Sedangkan, dalam tahap perancangan desain sistem, terdapat 22 use case dengan 7 use case utama yaitu pengelolaan sistem, pengelolaam e-learning, pengelolaan $e$ coaching, pengelolaan e-investation, pengelolaan e-auction, pengelolaan events notification, dan pengelolaan community group sehingga telah terbangun E-Incubator versi 1.0.0.

Penelitian ini memiliki beberapa keterbatasan yang dapat dijadikan saran untuk mengembangkan penelitian selanjutnya. Berikut adalah limitasi dan saran untuk pengembangan literatur: (1)Implementasi penelitian ini menggunakan studi kasus inkubator perguruan tinggi yaitu UPT Inkubator Industri ITS. Sehingga pada penelitian selanjutnya dapat menggunakan inkubator swasta atau pemerintah; (2)Berdasarkan hasil penelitian yang dilakukan, penulis berharap hasil rekomendasi model bisnis dan pengembangan system dapat diimplementasikan melalui kerjsama yang baik; (3)Saran dalam penelitian selanjutnya adalah mengenai aspek hak cipta dan legalitas E-Incubator sebagai platform pendukung pengembangan UKM berdasarkan kosep triple helix..

\section{DAFTAR PUSTAKA}

[1] Tempo.co, "Sri Mulyani Bedah Gejolak Perekonomian Global dan Indonesia," Jakarta, 2018.

[2] H. Etzkowitz and R. Viale, "Polyvalent Knowledge and the Entrepreneurial University: A Third Academic Revolution?," Crit. Sociol., vol. 36, no. 4, pp. 595-609, Jul. 2010, doi: 10.1177/0896920510365921.

[3] S. Rosyadi, "Revolusi Industri 4.0: Peluang dan Tantangan bagi Alumni Universitas Terbuka," Fak. Ilmu Sos. dan Ilmu Polit. Univ. Jenderal Soedirman, 2018.

[4] InfoDev, "Lessons on Virtual Business Incubation Services," 2011.

[5] and M. W. V. A. T. Eisenman, G. Parker, "Strategies for Two-Sided Markets," Hardvard Bus. Rev, vol. 84, no. 10, p. 92, 2005. 